\section{Sightings of Bath White Pontia daplidice MOOREI RÖBER, 1907 (LEPIDOPTERA: PIERIDAE: Pierinae: PierinI) from ARUnachal Pradesh AND NAGALAND, INDIA}

\author{
Tshetsholo Naro ${ }^{1} \&$ Sanjay Sondhi ${ }^{2}$ \\ ${ }^{1}$ North East Network, P.O. Chizami, Phek District, Nagaland 797102, \\ India \\ ${ }^{2}$ Titli Trust, 49 Rajpur Road Enclave, Dhoran Khas, Dehradun, \\ Uttarakhand 248001, India \\ ${ }^{1}$ tshetsholo@gmail.com, ${ }^{2}$ sanjay.sondhi1@gmail.com (corresponding \\ author)
}

The species Pontia daplidice Linnaeus, 1758, has a very widespread distribution from western Europe, northern Africa, eastward through west Asia, the western Himalaya in Pakistan and India, the central Himalaya in Nepal and south west China. The subspecies Pontia daplidice moorei Röber, 1907 is reported in the literature from the western Himalaya in Pakistan and India, the central Himalaya in Nepal as well as in northern Thailand, Laos and Yunnan.

Materials and Methods: The observations in this paper are part of an ongoing lepidoptera survey in the Kameng Protected Area Complex by Sanjay Sondhi. The survey, supported by the Rufford Small Grants program <www.ruffordsmallgrants.org/rsg/projects/ sanjay_sondhi> is documenting the butterfly and moth fauna of the area. The study area includes Pakke Tiger Reserve, Sessa Orchid Wildlife Sanctuary and Eaglenest Wildlife Sanctuary in the West Kameng District of Arunachal Pradesh. The methodology adopted for the butterfly survey was visual encounter surveys along fixed trails accompanied by photo-documentation of the butterflies seen. For cryptic species, the butterflies were netted, photographed and released. Permission for conducting the biodiversity assessments was received from the Arunachal Forest Department vide letter no CWL/G/13 (17)/06-07/12-14 dated

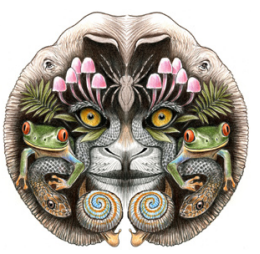

ISSN

Online 0974-7907 Print 0974-7893

\section{OPEN ACCESS} 06 January 2010.

Butterfly surveys have been ongoing in Chizami, Phek District, Nagaland since January 2011 as part of a biodiversity documentation program being conducted by the North East Network, Chizami.

Discussions: The lepidoptera survey in Kameng Protected Area Complex in western Arunachal Pradesh involved 60 days of field work spread over the months of May 2009, October 2010, March 2011, May 2011, September 2011 and April 2012. During the surveys, a single individual of $P$. daplidice moorei was recorded at Sessa Orchid Wildlife Sanctuary at 08:54hr on 28 March 2011 at an altitude of $900 \mathrm{~m}\left(27^{\circ} 06^{\prime} 02^{\prime \prime} \mathrm{N} \& 92^{\circ} 32^{\prime} 55^{\prime \prime} \mathrm{E}\right)$. A solitary individual of the subspecies was also recorded at $14: 58 \mathrm{hr}$ on 15 May 2011 at Langka $\left(27^{\circ} 01^{\prime} 15^{\prime \prime} \mathrm{N}\right.$ \& $93^{\circ} 02^{\prime} 22^{\prime \prime} \mathrm{E}$ ) in Pakke Tiger Reserve at an altitude of $170 \mathrm{~m}$. These records are the first ever reported sightings of this butterfly from Arunachal Pradesh (Images 1-2).

$P$. daplidice moorei was sighted on 27 March 2012 at $10: 35 \mathrm{hr}$ at Chizami $\left(25^{\circ} 24^{\prime} 0^{\prime \prime} \mathrm{N} \& 94^{\circ} 24^{\prime} 0^{\prime \prime} \mathrm{E}\right)$ in Phek District of Nagaland at an altitude of $981 \mathrm{~m}$. Subsequently, the butterfly has been seen on numerous occasions in Chizami during May-July 2012 and MarchApril in 2013, proving that it has established its presence in this locality (Images 3-4). A photographic record from Chizami of $P$. daplidice moorei was obtained on 12 April 2008 by Roshan Sahi, revealing that the butterfly has

DOI: http://dx.doi.org/10.11609/JoTT.o3308.4122-4 | ZooBank: urn:Isid:zoobank.org:pub:65F810D6-E222-465E-83FA-4F9C3CE8B9AF

Editor: Arun P. Singh, Rain Forest Research Institute (ICFRE), Jorhat India.

Date of publication: 26 April 2013 (online \& print)

Manuscript details: Ms \# 03308 | Received 17 August 2012 | Final received 02 January 2013 | Finally accepted 26 March 2013

Citation: Naro, T. \& S. Sondhi (2013). Sightings of Bath White Pontia daplidice moorei Röber, 1907 (Lepidoptera: Pieridae: Pierinae: Pierini) from Arunachal Pradesh and Nagaland, India. Journal of Threatened Taxa 5(7): 4122-4124; http://dx.doi.org/10.11609/JoTT.03308.4122-4

Copyright: @ Naro \& Sondhi 2013. Creative Commons Attribution 3.0 Unported License. JoTT allows unrestricted use of this article in any medium, reproduction and distribution by providing adequate credit to the authors and the source of publication.

Funding: Rufford Small Grants and North East Network.

Competing Interest: None.

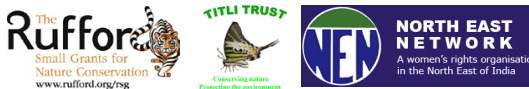

Acknowledgements: SS would like to acknowledge Rufford Small Grants for funding the Lepidoptera survey in the Kameng Protected Area Complex. TN would like to acknowledge North East Network (NEN) for its continued support in many ways. 

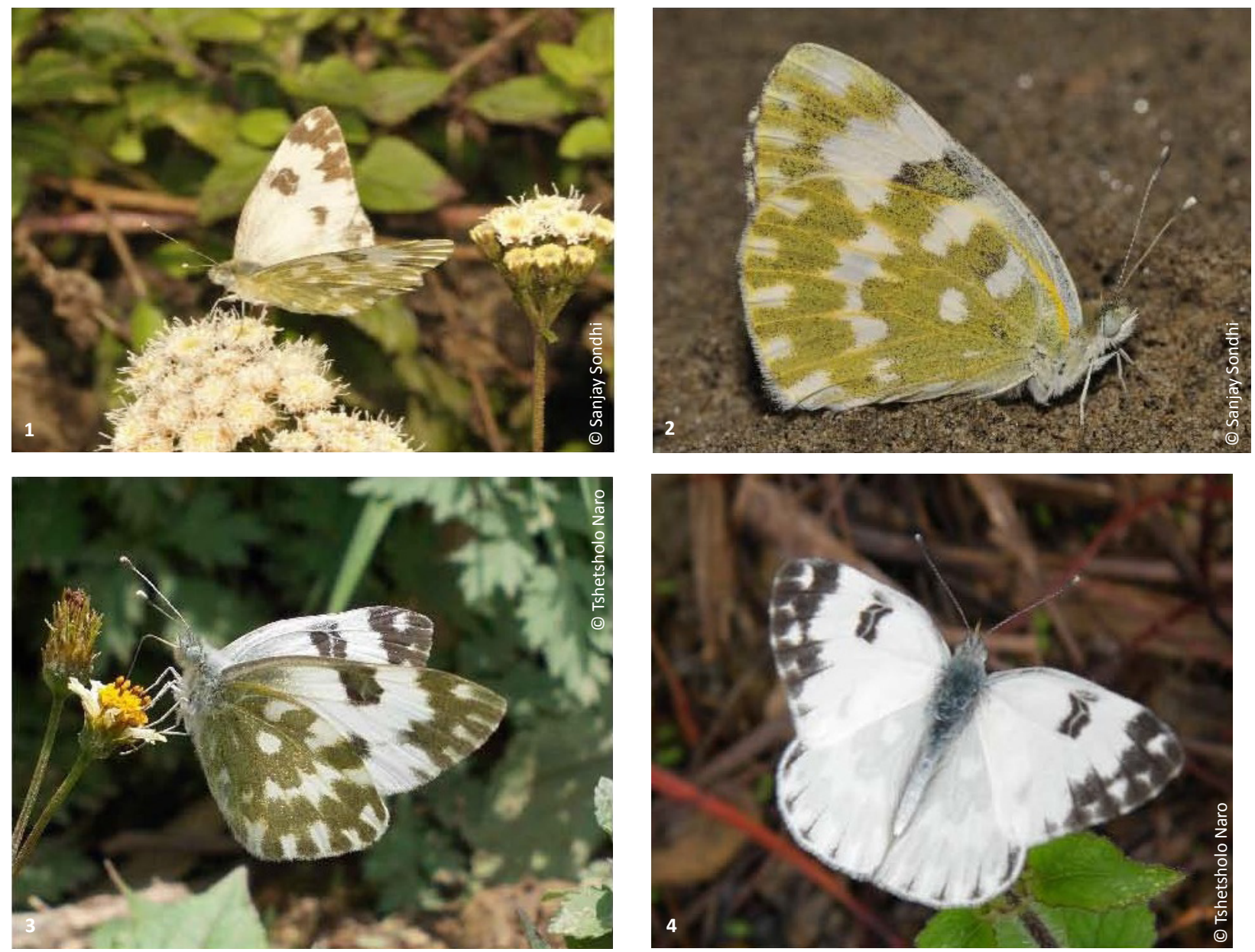

Images 1-4. Photographic records of Pontia daplidice moorei in Arunachal Pradesh and Nagaland

1 - Sessa Orchid WLS, West Kameng, Arunachal Pradesh, 28.iii.2011; 2 - Langka, Pakke Tiger Reserve, East Kameng, Arunachal Pradesh, 15.v.2011; 3 - Chizami, Phek District, Nagaland, 02.v.2012; 4 - Chizami, Phek District, Nagaland 02.vi.2012.

been present here, at least since 2008.

Perusing recent literature, Kehimkar (2008) reports the distribution of the butterfly from Jammu and Kashmir to Uttarakhand in India, which is also the distribution recorded by Singh (2010). Kehimkar also states that the butterfly is recorded from Afghanistan and Pakistan to the west and Nepal to the east.

Bingham (1907) reports its distribution in "western Himalaya" specifically mentioning Chitral, Ladakh, Kashmir and Baluchistan. Similarly, Evans (1932) reports its distribution as Baluchistan (in Afghanistan), east to Chitral (in Pakistan) and Murree (in Kashmir). Talbot (1939), too, restricts its distribution to northwestern Himalaya, exactly like Evans. Wynter-Blyth (1957) reports its distribution in Baluchistan, Chitral and Peshawar (both in Pakistan), Kashmir, east to Shipki (in Himachal Pradesh). Singh (2009) reports the presence of the species from Kedarnath in Uttarakhand. Smith
(1994) reports records from Nepal, stating it is "found in West to Central Nepal; scattered and fairly rare to the West, also in Central Terai". Smith also mentions that though it is common in Kathmandu Valley today it was absent in the 1930s. It is reported from Bhutan by van der Poel \& Wangchuk (2007), though Singh (2012) did not record it during a recent lowland forest survey conducted in Bhutan. Haribal (1992) does not report this species from Sikkim. Neither are there records of this subspecies from neighbouring countries namely Myanmar (Kinyon 2004) or Bangladesh (Larsen 2004). However, Inayoshi (2012) reports the distribution of the subspecies in "N.W. Himalayas, Northern Thailand, Laos, Tibet and Yunnan".

A review of older butterfly publications from northeastern India reveals that Captain Bailey recorded this subspecies during his expedition through western China, southeastern Tibet and Mishmi Hills in 1911 from 
"Liang ho kou" (South 1913) but did not record this subspecies during his expedition through southeastern Tibet in 1913 in what is now Arunachal Pradesh (Evans 1914). Betts (1950), too, did not record this in western Arunachal Pradesh, nor did Tytler (1915) report it from Manipur or the Naga Hills. There are no records of this subspecies in more recent surveys from Arunachal Pradesh by Athreya (2006), Borang et al. (2008), and Gogoi (2012).

Recent records of this subspecies from northeastern India include sightings in Keibul Lamjao in Manipur (Singh et al. 2011) and the website of the Indian Foundation of Butterflies (Anonymous 2013) which has photographic records of this subspecies from Buxa Tiger Reserve, West Bengal in March 2011 by Tarun Karmakar. Other records on the website are from Lower Mukung, West Sikkim District, Sikkim in May 2011 by Gaurav Agavekar and from Dzulekie, Kohima, Nagaland and in May 2012 by Krushnamegh Kunte.

A review of the altitudes at which this subspecies has been sighted is useful. Kehimkar (2008) stated that this is recorded between $1,200-2,700 \mathrm{~m}$, while stating that it migrates. Wynter-Blyth states that this is a butterfly primarily of the "higher inner hills, but it may be found on the plains at Peshawar in April. Common in the Valley of Kashmir". Our record at Pakke was at 170m in March, while the records in Sessa and Chizami were at higher altitudes, closer to its known altitudinal range.

Conclusion: These new locality records of Bath White $P$. daplidice moorei suggests that this subspecies has possibly been overlooked and has a wider distribution range in India than currently reported in the literature. It is also possible that the subspecies has colonized new areas in the north-east over time and is still doing so. $P$. daplidice moorei has been reared on Lepidium ruderale (Brassicaceae) in India (Sharma 2005), which is a temperate species, and is likely to be found throughout temperate India, including northeastern India, thereby permitting colonization by this species.

In India, the distribution of this subspecies is in the Himalaya and hills of north-east extending across Kashmir, Himachal Pradesh, Uttarakhand, Sikkim, West Bengal, Arunachal Pradesh, Nagaland and Manipur. Outside of India, the butterfly is known from Afghanistan, Pakistan, Nepal, Bhutan, southeastern Tibet, northern Thailand, Laos and southern China (Yunnan).

\section{REFERENCES}

Anonymous (2013). Pontia daplidice Linnaeus, 1758 - Bath White. In:
Kunte, K., S. Kalesh \& U. Kodandaramaiah (eds.). Butterflies of India. v. 1.06. Indian Foundation for Butterflies. <http://ifoundbutterflies. org/76-pontia/pontia-daplidice> (Accessed 1 January 2013)

Athreya, R. (2006). Eaglenest Biodiversity Project (2003-2006). Conservation Resources for Eaglenest Wildlife Sanctuary. Kaati Trust, Pune.

Betts, F.N. (1950). On a collection of butterflies from the Balipara Frontier Tract and the Subansiri area (northern Assam). Journal of the Bombay Natural History Society 49(3): 488-502.

Bingham C.T. (1907). The Fauna of British India including Ceylon and Burma. Butterflies-Volume II. Taylor and Francis Ltd., London.

Borang, A., B.B. Bhatt, M. Tamuk, A. Borkotoki \& J. Kalita (2008). Butterflies of Dihang Dibang Biosphere Reserve of Arunachal Pradesh, eastern Himalayas, India. Bulletin of Arunachal Forest Research 24(1\&2): 41-53.

Evans, W.H. (1932). The Identification of Indian Butterflies-2nd Edition. Bombay Natural History Society, Bombay, $\mathrm{x}+454 \mathrm{pp}+32 \mathrm{pl}$.

Evans W.H. (1914). A list of butterflies caught by Capt. F. M. Bailey in S. East Tibet during 1913. The Journal of the Bombay Natural History Society 23(1914): 532-546

Gogoi, M.J. (2012). Butterflies (Lepidoptera) of Dibang Valley, Mishmi Hills, Arunachal Pradesh, India. Journal of Threatened Taxa 4(12): 3137-3160; http://dx.doi.org/10.11609/JoTT.o2975.3137-60

Haribal, M. (1992). The Butterflies of The Sikkim Himalaya and Their Natural History. Sikkim Nature Conservation Foundation, Gangtok, 217pp.

Kehimkar, I. (2008). The Book of Indian Butterflies. Bombay Natural History Society and Oxford University Press, Oxford, xvi+497pp.

Kinyon, S. (2004). An Illustrated Checklist for the Butterflies of Myanmar. Smithsonian Institution, 197pp.

Larsen, T.B. (2004). Butterflies of Bangladesh - an annotated checklist. IUCN, Bangladesh, 158pp+8 colour plates.

Sharma, N. (2005). Life History of Pontia daplidice moorei (Röber) (Lepidoptera: Pieridae) from Himachal Pradesh, India. Journal of the Lepidopterists' Society 59 (3): 170-171.

Singh, A.P. (2009). Butterflies of Kedarnath Musk Deer Reserve, Garhwal Himalaya, India. Journal of Threatened Taxa 1(1): 37-48; http://dx.doi.org/10.11609/JoTT.o1873.37-48

Singh, A.P. (2010). Butterflies of India. Om Books International, $183 p$.

Singh, A.P. (2012). Lowland forest butterflies of the Sankosh River catchment, Bhutan. Journal of Threatened Taxa 4(12): 3085-3102; http://dx.doi.org/10.11609/JoTT.o2625.3085-102

Singh, I.M., A. Gupta \& R. Varathrajan (2011). Butterfly fauna of the the Keibul Lamjao National Park, Manipur, North East India. Current Science 101(6): 719-721.

Smith, C. (1994). Butterflies of Nepal. T.C. Majupuria (Ed.). Tecpress Service L.P. Bangkok, Thailand. Revised Edition.

South, R. (1913). A list of butterflies collected by Captain F.M. Bailey in western China, south-eastern Tibet and the Mishmi Hills, 1911. Journal of the Bombay Natural History Society 22(3): 598-615.

Talbot, G. (1939). The Fauna of British India including Ceylon and Burma. Butterflies. Vol. I. Taylor and Francis Ltd., London, 600pp.

Tytler, H. C. (1915). Notes on some new and interesting butterflies from Manipur and the Naga Hills. Part-II. Journal of the Bombay Natural History Society 23: 502-515+4 pls. (505).

Tytler, H.C. (1915). Notes on some new and interesting butterflies from Manipur and the Naga Hills. Part-III. Journal of the Bombay Natural History Society 24: 119-155 (135).

van der Poel, P. \& T. Wangchuk (2007). Butterflies of Bhutan Mountains, hills and valleys between 800 and $3000 \mathrm{~m}$. Royal Society for Protection of Nature (RSPN). Thimphu, Bhutan.

Wynter-Blyth, M.A. (1957). Butterflies of the Indian Region. Bombay Natural History Society, Bombay, $x x+523 p p+72 p l$.

Inayoshi, Y. (2012). A checklist of Butterflies in Indo-China Chiefly from Thailand, Laos and Vietnam. <http://yutaka.it-n.jp/pie/20400010. html $>$ (Accessed on 31/12/2012)

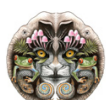

